\title{
TO THE ISSUE OF STUDYING PLANT PROTECTION PRODUCTS ACTIVE SUBSTANCES' BEHAVIOR INSIDE THE SURFACE AND GROUND WATER IN UKRAINE ACCORDING TO THE EUROPEAN UNION (EU) REGULATIONS
}

\author{
V. Chmil, G. Petrashenko \\ LI Medved's Research Centre of Preventive Toxicology, Food and Chemical Safety, Ministry of \\ Health, Ukraine (State Enterprise), Kyiv, Ukraine
}

\begin{abstract}
Purpose. To consider the study of the fate and behavior of active substances of plant protection products (AS PPP) in surface and groundwater in EU countries, the quality of surface and groundwater associated with the use of PPP in Ukraine and proposals for improving domestic monitoring of environmental and chemical status of surface and groundwater in Ukraine according to the EU regulations.

Materials and Methods. The presence of AS PPP in water in Ukraine is regulated by various legislative acts, including the Law on Drinking Water and Drinking Water Supply, the Order of the Ministry of Health of Ukraine on Approval of State Sanitary Norms and Rules "Hygienic Requirements for Drinking Water for Human Consumption", the Water Code of Ukraine, Ministers of Ukraine "Procedure for state water monitoring", the Law of Ukraine "On ensuring the sanitary and epidemiological well-being of the population" and others. Most of these documents take into account the safety criteria and quality indicators of drinking, surface and groundwater established in the EU. The Water Code of Ukraine and the Procedure for State Water Monitoring also take into account the main provisions of the EU Water Framework Directive in the field of protection of surface and groundwater from pollution by hazardous substances, including PPP. However, it should be noted that these documents use terms that are not in the EU documents and which misinterpret the terms and concepts that have become entrenched in world environmental science, in particular in the field of protection of surface and groundwater from contamination by hazardous chemicals. The use of such terms undoubtedly complicates the intended use of Ukrainian documents.

Conclusions. Proposals have been formulated on the inappropriateness of using in the legislative acts of Ukraine in the field of water policy some concepts and terms that does not meet EU requirements and have expired and are not used in Ukraine according to the Order of the Cabinet of Ministers of Ukraine №94-r from 20.01.2016.

When state registration in Ukraine of PPP of foreign production, which have passed the necessary tests in EU countries, in the dossier for the formulation registered and submitted by the Applicant, the values of predicted concentrations of DR PPE in soil, surface and groundwater and air must be given. characterize the risk to humans and non-target organisms.

Key Words: active substances of plant protection products, surface waters, groundwater, environmental quality standards, predicted ecological concentrations of active substances of plant protection products, monitoring of ecological and chemical condition of surface and groundwater.
\end{abstract}

Introduction. Plant protection products (PPPs) are an integral part of modern agriculture, the whole branch of agricultural production. These are complex chemical compounds that are used deliberately, with the specific purpose of destroying pests, to increase yields and profitability. Agriculture is one of the few human activities where chemicals are introduced into the environment as a killer to control a wide variety of insectivorous and herbaceous pests that adversely affect the quantity and quality of food produced. Unfortunately, over time, along with these advantages of using PPPs, humanity has faced disadvantages, some of which are so dangerous and serious that there is now a real threat to the long-term survival of major ecosystems due to predator-vic- tim distortions. This can lead to biodiversity loss, not to mention that PPP can have a serious negative impact on human health [1]. Therefore, careful management is needed to avoid dangerous and uncontrolled pollution of the environment, including water resources the most important component of the life of all terrestrial beings after the air.

Water is the main means of transport of active substances of PPP (AS PPP) to the environment. As noted in Directive 2000/60 of the European Parliament and of the Council establishing a framework for Community action in the field of water policy [2], "water is not a commercial product like any other, but rather, a heritage which must be protected, defended and treated as such". About $97 \%$ of 
the world's water reserves are in the oceans. The remaining $3 \%$ is fresh water, of which about $70 \%$ is stored in glaciers in the form of ice. Almost all unfrozen freshwater on earth is in underground aquifers and only $1 \%$ is in natural and artificial surface water bodies such as streams, rivers or canals, ponds, lakes and reservoirs [3]. Surface and groundwater are the main sources of drinking water, i.e. water intended for human consumption [4].

\section{Sources of AS PPP in surface and groundwater}

Regular use of sustainable AS PPP on agricultural land causes pollution of surface and groundwater. AS PPP can enter reservoirs and river systems from point sources, i.e. from certain places near the reservoir and along the river or from diffusion sources along the boundaries of the reservoir or the entire riverbed [5]. In addition, in open reservoirs AS PPP can enter the aviation treatment of PPP of agricultural areas and forests, with the direct use of open water bodies on the water surface to destroy algae, mollusks, vectors of human and animal diseases and weeds, as well as in urban settlements (roads, tram tracks, city parks and squares).

\section{Point sources}

Numerous studies have shown that the penetration of AS PPP into the river systems of European countries by $20-80 \%$ is due to point sources [5-9]. Such are the treatment facilities of enterprises that discharge wastewater, sewage overflows, as well as poor agricultural practices due to improper use of equipment for the use of PPP [10]. Increased concentrations of AS PPP in surface waters, which are observed during dry seasons. Specialists contribute to the pollution when filling the equipment with PPE solutions, spilling it on the ground, as well as without following the proper practice when cleaning this equipment, or using outdated samples.

\section{Diffusion sources}

AS PPP enters river systems from diffusion sources, which absorb surface runoff from areas of PPP application, aerosol depletion formed as a result of their use, evaporation with subsequent precipitation. It is also necessary to take into account soil erosion under the influence of precipitation and wind, leaching from the soil of water-soluble AS PPP as a result of irrigation and connection with groundwater.

\section{Surface runoff and soil erosion}

Surface runoff is formed as a result of the movement of rain and melt water on the sloping surface of areas treated with PPP, which can contaminate rivers, streams, ponds, lakes and wells. Based on the simulation, it was shown that the surface runoff is the main source of diffuse inflow of AS PPP into water sources, in particular in Germany [11]. The reason that causes surface runoff is the excess of water flow to the earth surface as a result of precipitation, melting snow or irrigation over the rate of its penetration into the soil [5]. The amount and velocity of surface runoff depend on both the parameters of precipitation or irrigation (irrigation) and the parameters of the catchment. Precipitation (or irrigation) parameters include their duration, intensity, timing and distribution over the area of the cultivated area. Important characteristics of the catchment area that affect the surface runoff are soil properties, land use, vegetation, soil moisture, size, shape, relief, orientation and geology, application practice and type of PPP used [12].

Surface runoff is the cause of water erosion in the collision of water droplets (rain, irrigation) with the soil surface, therefore, as a result of which soil particles are displaced and move with it. AS PPP, which are transferred with surface runoff, can be in solution as well as in the adsorbed state by soil particles. The distribution of AS PPP between the solution and the solid phase of the soil is determined by the content of organic carbon and clay in the soil. The transport of AS PPP as a result of surface runoff is a much more characteristic phenomenon for soluble AS PPP than the transport of soil particles that have been eroded, because the size of the latter is usually much smaller compared to the volume of surface runoff [13]. Only for highly adsorbing AS PPP erosion is considered as the main means of transport from the application site [14]. The amount of AS PPP that enters river systems with surface runoff depends on the amount of AS PPP on the soil surface at the time of runoff and is determined by the period of time between the application of PPP and the first precipitation and the rate of application [15]. The greatest 
inflow of AS PPP into surface waters is observed when heavy precipitation occurs immediately after the application of PPP.

\section{Drift of aerosol}

Drift of the aerosol formed during the application of PPP is the transfer by air of sprayed drops of PPP from the application site. The amount of wear PPP depends on the size of the droplets formed (wear increases with decreasing droplet size), wind speed (with strong wind wear increases) and the distance between the nozzle of the spray device and the treated plants or soil (greater distance increases wear). Part of the formed aerosol can be transferred from the treated areas by wind or air flow of the spray and reach the nearest river systems [11]. Airborne PPP residues are subject to various degradation processes, including photodegradation, oxidation, and hydrolysis, and are often rapidly degraded in the atmosphere [16]. However, the residues of stable AS PPP may pose a certain risk for surface water pollution. Drift of PPP aerosol particles is a complex problem, the significance of which is determined by the interaction of such parameters as the design of the equipment used, the application rate of PPP, the physical properties of the applied PPP formulation and the resulting aerosol, meteorological conditions at the time of application [17]. However, based on a number of publications, the contribution of spraying of the sprayed PPP aerosol to surface water pollution is considered to be quite small $[5,18$, 19, 20].

\section{Leaching}

Contamination of groundwater of the Far East PPP can occur as a result of leaching, i.e. the process of leaching from the soil into the water of the AS PPP, soluble in water. Sources of groundwater pollution, in addition to special areas, can be sites for preparation of solutions and washing equipment for the use of PPP or areas for waste disposal.

In the process of leaching AS in water there are two types of filtrations through the soil: the predominant flow and matrix flow [3]. The predominant one is water, which flows rapidly through root canals, holes formed by earthworms, cracks and large structural cavities in the soil. The rapid movement of AS PPP molecules with a predominant water flow reduces the likelihood of their sorption by soil particles or microbial degradation. The matrix flow is formed by water, which flows slowly through small pores in the soil structure, as a result of which the contact time for the molecules of AS PPP with soil particles increases. The closer the groundwater level is to the surface, the more likely it is to become contaminated.

The ability to leach AS PPP from soil into groundwater is determined by the solubility of AS PPP in water and depends on their adsorption by soil particles. Clay soils have a high ability to adsorb AS PPP, while sandy soils are characterized by a much lower ability. Soil organic matter also has the following properties in relation to AS PPP.

The method of getting water on the soil surface and the timing of precipitation or irrigation are also important. It is unlikely that small volumes of water at long intervals will contribute to the leaching of long-term PPP in contrast to large volumes of water in shorter periods of time. Precipitation or irrigation that occurs shortly after the application of PPP increases the leaching of AS PPP from the soil. Table 1 shows the risks of contamination of groundwater AS PPP due to leaching [21].

Contamination of deep groundwater is possible, but locally and in low concentrations [5]. This is due to the fact that surface waters are polluted due to leaching of PPP.

In the future, diffusion routes of PPP entering surface waters as a result of atmospheric precipitation after evaporation, as well as the precipitation of erosive soil particles together with adsorbed AS PPP, which caused the wind [5].

As a result of monitoring of AS PPP in surface waters, in particular herbicides, it was found that less than $2 \%$ of the total amount of PPP used in the area of large catchments enters surface waters [5]. And this happens mainly and immediately after the application of PPP. Monitoring studies have also shown that the possibility of contamination of surface and groundwater AS PPP is determined by the following factors:

1. Type and properties of soil at the site of application of PPP;

2. Properties of PPP and their active substances;

3. Weather conditions;

4. Hydraulic load on the ground;

5 . The method (practice) of growing crops (crop production) [16, 20, 22]. 
Risk of groundwater pollution

\begin{tabular}{|c|c|c|}
\hline Characteristics of AS PPP & Low risk & High risk \\
\hline Solubility in water & Low & High \\
\hline Soil adsorption & Strong & Weak \\
\hline Stability & Low & \\
\hline Soil characteristics & & Coarse-grained sand \\
\hline Texture & Thin clay & Low \\
\hline Organic substance content & High & Many, big \\
\hline Macropores & A few, small & Shallow (6 m or less) \\
\hline Depth of groundwater & Deep (30 m or more) & \\
\hline Volume of water & & Large volumes, often \\
\hline Precipitation / irrigation & Small volumes, rarely & \\
\hline
\end{tabular}

\section{Processes occurring with AS PPP} in surface waters

Once AS PPP enters water sources, they are subjected to various physical, chemical and microbiological processes that affect their fate and behavior in water. These processes include hydrolysis, photolysis, evaporation, sedimentation, adsorption/desorption, biodegradation, bioaccumulation and biotransformation [5]. Some of them lead to a change in the structure of the AS molecule PPP or its complete destruction.

\section{Hydrolysis}

Hydrolysis is a chemical reaction that occurs in water. It leads to abiotic degradation of the AS PPP molecule, as a result of which part of the AS PPP molecule is replaced by $\mathrm{OH}$ groups with the formation of less hydrophobic hydroxy analogues [3], most of which do not have toxic properties for aquatic organisms. However, the hydrolysis products formed, alone or in combination, should not be considered as non-toxic. Such products can be formed not only through hydrolysis, but also as a result of water treatment, purification and disinfection [23]. The degree of degradation depends on $\mathrm{pH}$. Organophosphorus PPPs and carbamates are the easiest to hydrolyze.

\section{Photolysis}

Photolysis is one of the most important abiotic transformations of long-range PPP in the aquatic environment due to the action of visible radiation of sunlight. It causes characteristic reactions, including cleavage, cyclization and rearrangement. They are most likely not observed in the processes of hydrolysis and microbial degradation of AS PPP [24]. Photolysis occurs on the surface of water, where sunlight can penetrate.

\section{Evaporation}

Evaporation is a process in which AS PPP (solids or liquids) with high vapor pressure and low solubility in water evaporate into the atmosphere as a gas [3]. As a result of evaporation, some AS PPP are transported with air over long distances. The tendency to evaporate AS PPP from water is approximated by the ratio of its vapor pressure to solubility in water. The same is partly true for soils, but the tendency to evaporate long-term PPP from the soil can also be inversely proportional to its ability to bind soil particles.

Environmental factors that increase the evaporation of AS PPP include high temperature, relatively low humidity and air movement. As a result of strong adsorption of AS PPP by soil particles, its concentration in the soil solution decreases and this leads to a low probability of its evaporation. Thus, less evaporation occurs from dry soils because the lack of water allows AS PPP to be adsorbed on soil particles. AS PPP with a vapor pressure of more than $10-6 \mathrm{~mm} \mathrm{Hg}$ pose a danger of air pollution [25].

\section{Sedimentation}

Surface waters in streams, rivers and canals can carry dissolved AS PPP, which are adsorbed on suspended (suspended) soil parti- 
cles [3]. Suspended particles are formed as a result of soil erosion, as well as washed away by water from the sides and bottom of water sources. When water flows with suspended particles reach the water in the reservoir (pond or lake), the flow rate decreases significantly and there is a sedimentation process, as a result of which most of the large and heavy particles settle to the bottom of the reservoir under gravity. Smaller particles of light materials, such as clay, may remain suspended for longer periods, although the concentrations of contaminants due to dilution in the reservoir water may be lower than in the stream.

\section{Adsorption}

Adsorption along with biodegradation belongs to the processes that affect the share of AS PPP in water sources. Common to these processes is that they strongly depend on the presence of sediment in water systems [5].

The content of AS PPP in water sources is largely determined by their adsorption properties. First of all, adsorption strongly influences the movement of AS PPP from the site of their application to water sources. AS PPP, which are poorly adsorbed by soil particles, are likely to move along the soil profile with surface runoff and leached into groundwater. In addition, adsorption can affect the process of AS PPP degradation due to their chemical reactivity. After all, the adsorbed state differs significantly from the reactivity of AS PPP in solution [5]. Thus, natural sorbents, which are involved in the formation of sediments in water sources, can indirectly control the processes of absorption or release of AS PPP.

The adsorption of AS PPP by soil is measured by the Koc coefficient, which is the ratio of the concentration of adsorbed chemical in the soil, taking into account the organic carbon content to the concentration of chemical remaining in water and serves to assess the tendency of AS PPP to adsorb soil particles [16]. The values of the Koc coefficient allow to estimate the potential mobility of AS PPP in the soil. High values of Koc (over 1000) belong to AS PPP, which are strongly adsorbed by the soil and have low mobility in the soil in the absence of soil erosion. Low values of Koc (300-500) belong to AS PPP, which are able to move with water, therefore, have the potential for leaching or movement with surface runoff.

AS PPP with high solubility in water, low ability to adsorb soil particles and long-term stability and half-life has the highest ability to move into the water from the areas of application of PPP. These three parameters are commonly used to assess the ability of AS PPP to be leached from the soil or transferred to surface runoff after PPP application.

The solubility of AS PPP in water is used to assess the possibility of washing AS from the surface of the treated crop as a result of irrigation or precipitation, its penetration into the depth of the soil or movement with surface runoff. AS PPP with water solubility at the level of 1 part per million (1 ppb) remain on the soil surface, do not leach, do not move with surface runoff in the absence of soil erosion. The solubility of AS PPP at the level of $\geq 30$ parts per million $(30 \mathrm{ppb})$ characterizes its ability to leach and move with surface runoff.

Finally, the longer the half-life of AS PPP (more than 20 days), the higher the ability to leach and move with surface runoff until it collapses.

\section{Biodegradation}

Biodegradation is the destruction of chemicals by microorganisms such as fungi and bacteria. Surface water is a good environment for the destruction of AS PPP, especially when microorganisms attach to surfaces such as sediments, stones and plants [5]. Microorganisms that inhabit wetlands in terrestrial systems or live in the bottom sediments of rivers, lakes or ponds, destroy AS PPP as a result of anaerobic metabolism to carbon dioxide, methane and water [3] These microorganisms are also present in groundwater. In some publications, it has been suggested that the adsorption of AS PPP on suspended solids and sediments containing organic carbon reduces the rate of destruction of AS PPP in aqueous systems [26, $27,28]$. In natural systems, the routes and rate of biodegradation depend on the type of substrate, temperature, oxygen availability, nutrient supply, the similarity of the connection with other power sources. In the sediment, many types of compounds will degrade more slowly below the oxygen zone of the bottom sediment and therefore can be stable [29].

\section{EU legislation on water policy in relation} to the use of PPPs in agricultural practice

The existence of PPP in water in the EU is regulated by various important documents, including the Drinking Water Directive [30], 
the Water Policy Framework Directive [2], which have been amended over time [31, 32], and the Groundwater Directive [33].

According to the Drinking Water Directive, the concentration of any individual PPP in drinking water should not exceed $0,1 \mu \mathrm{g} / 1$, and the total concentration, i.e. the sum of all individually detected PPPs, their significant metabolites, reaction products and destruction should not exceed $0,5 \mu \mathrm{g} / 1$.

The EU Water Framework Directive 2000/60 of the European Parliament and of the Council established a strategy for action and a basis for assessing, managing, protecting and improving the quality of water resources throughout the EU and established environmental quality standards (EQS). For water, this standard regulates the established concentration of a particular pollutant, group of pollutants in water, sediments or biota, which should not be exceeded, in order to protect human health and the environment [2]. Pollutants are divided into hazardous substances, priority substances and priority hazardous substances. Hazardous substances include substances or groups that are toxic, persistent and bioaccumulative, as well as other substances or groups of concern that cause an equivalent level of concern. Priority substances are those that pose a significant risk to the aquatic environment, which, in turn, once ecotoxicity has been identified, may adversely affect human health through the aquatic environment and the aquatic ecosystem as a whole. Finally, priority hazardous substances are those that raise concerns about compliance with current EU legislation, as well as international agreements on hazardous substances.

Framework Directive 2000/60/EC defined the concept of "good status of surface and groundwater", i.e. due to their environmental and chemical status.

In turn, the ecological status of water systems with surface waters is determined in accordance with the standards of their biological, hydromorphological and physicochemical quality elements. Good chemical status of surface waters is determined by the concentrations of pollutants, which should not exceed the established values of EQS. Directive 2008/105 of the European Parliament and of the Council has drawn up a list of priority pollutants for water policy, which includes
33 chemical compounds [31]. Directive 2013/39 / EU of the European Parliament and of the Council established the EQS and the maximum allowable concentrations for EQS (MAC-EQS) for priority pollutants in accordance with the provisions and objectives of Directive 2000/60 / EC [32]. In Table Figure 2 shows the values of the average annual values of EQS and MAC-EQS in surface water for priority.

Directive 2006/118 of the European Parliament and of the Council on the protection of groundwater against pollution and depletion established a groundwater quality standard which is expressed as the concentration of a pollutant, group of pollutants or their indicators in groundwater, which must not be exceeded to protect people's health and the environment [33]. The quality standard, i.e. the concentration of individual AS PPP in groundwater should not exceed $0,1 \mu \mathrm{g} / 1$, and the total amount of AS PPP, as well as metabolites, degradation products and reactions should not exceed $0,5 \mu \mathrm{g} / 1$.

\section{Development of data on the fate and behavior of PPP in surface and groundwater in $\mathrm{EU}$ countries}

In order to place on the market AS PPP and the relevant wording, as well as to register for use in EU agricultural practice in accordance with Commission Regulations №1107/2009 and №540/2011 [34, 35], the applicant must submit a dossier with data relating to the fate and behavior of AS PPP and formulations in surface and groundwater and sediments. These data must comply with the requirements of Commission Regulation (EC) №283/2013 [36] and Commission Regulation (EU) №284/2013 [37], be sufficient to establish or approve the assessment of AS PPP and include:

a) stability of AS PPP in water systems (bottom sediments and water, including suspended particles);

b) the degree to which water and benthic organisms are exposed to the risk of exposure;

c) the possibility of pollution of surface and groundwater.

The data provided regarding the routes and rates of degradation of AS PPP in aquatic systems, including chemical and photochemical degradation, should be sufficient to: 
Environmental quality standards (EQS) for priority active substances of PPP

\begin{tabular}{|l|c|c|}
\hline AS PPP name & $\begin{array}{c}\text { AC- EQS, } \boldsymbol{\mu g} \text { / I } \\
\text { Internal surface waters }\end{array}$ & $\begin{array}{c}\text { MAC-EQS, } \boldsymbol{\mu g} \text { / I } \\
\text { Internal surface waters }\end{array}$ \\
\hline Alachlor & 0,3 & 0,7 \\
\hline Atrazine & 0,6 & 2,0 \\
\hline Chlorfenvinphos & 0,1 & 0,3 \\
\hline Chlorpyrifos (chlorpyrifos-ethyl) & 0,03 & 0,1 \\
\hline $\begin{array}{l}\text { Cyclodienes: } \\
\text { Aldrin } \\
\text { Dildrin } \\
\text { Endrin } \\
\text { Isodrine }\end{array}$ & $\mathbf{\Sigma}=0,01$ & Not applicable \\
\hline DDT (total amount) & & Not applicable \\
\hline Para-para-DDT & 0,025 & Not applicable \\
\hline Diuron & 0,01 & 1,8 \\
\hline Endosulfan & 0,2 & 0,01 \\
\hline Hexachlorobenzene & 0,005 & 0,05 \\
\hline Hexachlorobutadiene & 0,01 & 0,6 \\
\hline Hexachlorocyclohexane & 0,1 & 0,04 \\
\hline Isoproturon & 0,02 & 1,0 \\
\hline Pentachlorophenol & 0,3 & 1,0 \\
\hline Simazine & 0,4 & 4,0 \\
\hline Trifluralin & 1,0 & Not applicable \\
\hline
\end{tabular}

1) determining the relative complexity of all processes involved in degradation (balance between chemical and biological degradation);

2) the possibility of identifying individual available degradation products;

3 ) establishing the relative ratio of the detected degradation products and their distribution between water, suspended particles and sediment;

4) the possibility of determining the balance of AS PPP, which causes a state of concern that may occur in certain non-target species.

According to Commission Regulation (EU) №284/2013 [37] it is also necessary to conduct a study of the stability and behavior of PPE in surface waters and sediments, including fresh, estuarine and marine waters, in case of impossibility to use data obtained for AS PPP and metabolites, products schedule and response in accordance with the requirements of Commission Regulation (EU) №283/2013 [36].
Study of hydrolytic degradation

Studying the chemical (hydrolytic) degradation, it is necessary to determine the rate of hydrolysis for pure AS PPP at $20^{\circ} \mathrm{C}$ or $25^{\circ} \mathrm{C}$. Hydrolytic degradation studies should also be performed for decomposition and reaction products that account for more than $10 \%$ of the amount of long-term PPP added in the hydrolysis study. No additional information on hydrolysis of products is required if they are considered stable in water. Estimates for the half-life of AS PPP (DegT50) should be reported for $20^{\circ} \mathrm{C}$ or $25^{\circ} \mathrm{C}$.

\section{Study of photochemical degradation}

The study of photochemical degradation in water is similar to hydrolysis experiments, but they are carried out in the presence of artificial or sunlight. For compounds with a molar absorption coefficient $(\varepsilon)>101 \times$ mol- $1 \times \mathrm{cm}$ 1 at a wavelength $(\lambda)$ of $295 \mathrm{~nm}$, direct photo- 
chemical degradation of pure AS PPPs should be determined and reported unless the applicant provides evidence that there will be no surface water pollution. Direct photochemical degradation studies should also be performed for metabolites, degradation products, and AS PPP reaction products that account for more than $10 \%$ of the amount of substance added in the photolysis study. No additional information on photolysis of products is required if they are considered stable under photolysis. The photochemical half-life of AS PPPs (DT 50) must be reported.

\section{Study of biological degradation}

When studying the biological degradation of AS PPP in surface waters, as a consequence of aerobic mineralization, it is necessary to provide data and information that would be sufficient for:

a) identification of the individual components present that make up more than $10 \%$ of the amount of added substance, including, where possible, non-recoverable residues;

b) identification of the individual components present, which account for more than $5 \%$ of the amount of the substance added, in at least two consecutive measurements;

c) identification of individual components ( $>$ $5 \%$ ) for which at the end of the study the maximum formation has not yet been reached;

d) identification or characteristics of other individual components, where possible;

e) establishing the relative proportions of the components (mass balance), where appropriate;

f) permission to identify, where appropriate, residues of suspicious sediments in order to prevent effects on non-target species that may be adversely affected.

The duration of the study should not exceed 60 days, but may be extended to a maximum of 90 days if decomposition has begun within the first 60 days. Similar studies in the study of biological degradation of AS PPPs should also be conducted in the water / bottom sediment system.

According to Commission Regulation (EU) №284/2013 [37], the stability and behavior of PPPs in surface waters and sediments, including fresh, estuarine and marine waters, should also be investigated, unless extrapolation of data obtained for AS PPPs and metabolites, decomposition products is possible. and reactions in accordance with the requirements of Commission Regulation (EU) №283/2013 [36].

\section{Predicting the fate and behavior of AS PPP in the environment}

The behavior of AS PPPs in the environment can be to some extent predictable [16]. The AS parameters used for their environmental fate include the half-life, soil sorption coefficient, water solubility, vapor pressure, Henry's law constant, and the Groundwater Ubiquity Score (GUS), which shows how strong PPP is maintained by the organic fraction of the soil and which is calculated using the half-life and the sorption coefficient [38, 39]. To predict the fate and behavior of AS PPP, including surface and groundwater, sediments, it is possible only comprehensively taking into account the above parameters, taking into account the type of soil and environmental conditions.

According to Commission Regulation (EU) № 284/2013, the actual assessment of the risk to humans and the environment associated with the use of PPP should be made on the basis of the predicted (expected) concentrations (PC) of the active substance PPP, its significant metabolites, degradation products and reactions data objects. Predicted environmental concentration (PEC) is the predicted concentration of a chemical in the environment, calculated on the basis of available information about its properties, methods and amount of application [40]. To assess the risk to humans and the environment through PPPs, the predicted concentrations of long-term PPPs have been developed:

a) predicted ecological concentration in the soil (PECs): the level of AS PPP residues in the upper soil layer, which may affect nontarget soil organisms (acute and chronic effects);

b) predicted ecological concentration in surface water (PECsw): the level of AS PPP residues in surface water may affect nontarget organisms (acute and chronic effects).

c) predicted ecological concentration in the sediment (PECsed): the level of DR PP residues in the sediment, which may affect non-target benthic organisms (acute and chronic effects). 
d) projected ecological concentration in groundwater (PECgw): the level of AS PPP residues in groundwater.

e) predicted environmental concentration in the air (PECa): the level of AS PPP residues in the air can affect humans, animals and other non-target organisms (acute and chronic effects).

Therefore, for the predicted concentrations, in order to assess the risks to human health associated with the use of PPPs, the EU takes into account the concentration of AS PPP $\mathrm{s}$ in only one component of the environment - air. However, when assessing the risks associated with residues of AS PPP in surface and groundwater, the impact of AS PPP on both natural ecosystems and humans must be taken into account, as surface and groundwater serve as sources of drinking water consumed by humans [41]. To do this, it is widely used to compare the predicted concentrations of AS PPP, for example, in surface water (PECsw) with the predicted no effective concentration of AS PPP (PNEC), which does not observe any toxic effects on a particular organism during ecotoxicity experiments and which usually calculated from $\mathrm{LC}_{50}$ values [42] The ratio of these concentrations is called the risk quotient (RQ) [43]:

$$
\mathrm{RQ}=\mathrm{PEC} / \mathrm{PNEC}
$$

If the RQ is less than or equal to 1 , this indicates the absence of significant risk associated with the presence of AS PPP in surface water, no additional information and/or testing is required, the risk is under control and the PPP formulation can be placed on the market. If RQ $>1$ it means that the risk is uncontrolled and the further characteristic of risk is necessary.

The procedure for registration of PPP in the EU in accordance with Commission Regulation (EU) №1107/2009 includes the possibility of using models for the calculation of PC in surface waters of the working group FOCUS (FORUM for coordination of models of the share of pesticides and their use) [44]. Depending on the size of the RQsw, additional toxicological studies may be required to decide on the registration of PPPs to demonstrate an acceptable risk to aquatic organisms. The stepby-step procedure for calculating PECsw is carried out in four stages [45]. The first stage is using simple kinetics and the rate of use of
PPP, equivalent to the maximum annual application. The second stage is to assess the timeweighted concentrations taking into account successive (several) applications of PPP. With the help of the third stage, a more detailed modeling is carried out, which takes into account the real "worst" amounts of PPP entering the surface waters along certain possible routes (surface runoff, demolition, drainage, precipitation). Finally, in the last fourth stage, the quantities of PPP provided in the third stage are considered, but taking into account the possible ranges of use. It is necessary to take into account specific and real combinations of farming methods, soil type, weather conditions, field topography and water bodies adjacent to agricultural fields.

Scenarios have been developed for three simulation models that take into account the impact of drainage, runoff and fate on the assessment of the final PECsw. The MASRO model is used to assess drainage as a result of subsurface PPP penetration into surface waters [46], the PRZM model is designed to account for runoff into surface PPP penetration into surface waters [47] and finally the TOXSWA model takes into account PPP scattering processes in surface waters [48]. The results of the MACRO and PRZM models are used as input to the TOXSWA model in addition to the aerosol demolition data. Final PECsw, calculated using the TOXSWA model, to assess the risk of toxic effects of AS PPP on aquatic organisms.

A General Guide based on the FOCUS Working Group scenario for Level 1 groundwater assessment has also been developed [49]. The most important parameters of AS PPP for the model of calculation of PECsw and PECsed are [45]:

- half-life (DegT50) in soil at $20^{\circ} \mathrm{C}$ (days),

- half-life (DegT50) in water at $20^{\circ} \mathrm{C}$ (days),

- half-life (DegT50) in the sediment at $20^{\circ} \mathrm{C}$ (days),

- the coefficient of distribution of organic matter (Com) and the corresponding adsorption constant $1 / \mathrm{n}$ for soil $(\mathrm{l} / \mathrm{kg})$,

- the partition coefficient of organic matter (Com) and the corresponding adsorption constant $1 / \mathrm{n}$ for suspended organic matter $(1 / \mathrm{kg})$,

- the coefficient of distribution of organic matter (Com) and the corresponding adsorption constant $1 / \mathrm{n}$ for sediment $(1 / \mathrm{kg})$ 
(conversion factor Koc in Kom 1,724),

- saturated vapor pressure (PA),

- solubility in water $(\mathrm{mg} / \mathrm{l})$,

- molecular weight $(\mathrm{g} / \mathrm{mol})$.

In addition, the level of PEC depends on the following factors: application rates of PPP $(\mathrm{kg} / \mathrm{ha})$, frequency of application, time between successive applications (days), route of exposure (drift, drainage and runoff), mitigation measures.

To verify the accuracy of the developed models for calculating the predicted concentrations of AS PPP in surface waters, we can compare the measured concentrations obtained on the basis of detection and quantification of residues of specific AS PPP in surface water with the calculated values of RQsw.

It should be noted that the routes of PPP penetration into surface waters and subsequent RQsw of AS PPP will differ in different EU countries [32] depending on national agricultural practices and environmental conditions (including climate). In this regard, the conditions for registration of PPE in different EU Member States will also differ. Therefore, in some EU countries, in addition to the use of zonal PPP assessment procedures in accordance with Commission Regulation (EU) №1107/2009, which strengthens the principle of mutual recognition of PPP registration in the EU [34], individual risk mitigation measures may be applied.

\section{Monitoring of long-range PPP}

\section{in surface and groundwater in the EU}

EU Member States monitor the ecological and chemical status of surface water in rivers, lakes, transitional and coastal waters and artificial reservoirs, as well as the chemical status of groundwater through an appropriate network established in accordance with Directive $2000 / 60 / \mathrm{EC}$ [2] and with the provision of a map or maps showing the surface and groundwater monitoring network in terms of river basin management.

The ecological status of surface waters is an assessment of the quality of the structure and functioning of surface water ecosystems, including rivers, lakes, transitional and coastal waters, which shows the impact of pollution and environmental degradation based on monitoring of biological quality elements (phytobenthos, phytoplankton, macrophytes, benthic invertebrates). and supporting physic- ochemical (nutrients, oxygen, temperature, transparency, salinity, pollutants characteristic of the reservoir) and hydromorphological (hydrology, morphology, barriers) quality elements. Ecological condition is an indicator of surface water health, characterized by biological quality elements, can be high, good (good), medium (moderate), bad.

The chemical status of surface waters is determined by the limits (environmental quality standards, NMS) of the concentration of certain pollutants in surface waters detected in the EU, known as priority substances.

The chemical status of groundwater depends on the ingress of hazardous substances into groundwater, as well as all other pollutants. The chemical state of surface and groundwater is assessed as "good".

Based on the characteristics of the water basin, consideration of the impact of human activities on the state of surface and groundwater and economic analysis of water use, programs of supervisory and operational monitoring should be developed. In some cases, EU Member States may need to develop research monitoring programs.

Surveillance monitoring should be carried out on a sufficient number of surface water bodies to ensure the assessment of the general status of surface waters within each catchment area or catchment area within the river basin district for one year at intervals covered by the river basin management plan from the list of priority chemical surface water pollutants that may enter the river basin.

Operational monitoring should be carried out to determine the status of those reservoirs that are at risk of deterioration of their ecological status, and to assess any changes in the status of such reservoirs based on the identification of active PPE substances that are on the list of priority chemical surface water contaminants. in such reservoirs.

Research monitoring is carried out when the reasons for the deterioration of the ecological or chemical status of the water body are unknown, and observational monitoring data show that the measures taken to achieve good ecological and chemical status of the water body do not lead to positive results. In such a situation, operational monitoring is not yet in place to establish the causes of this situation, to determine the extent and consequences of accidental pollution, to develop programs of 
measures to eliminate the causes and consequences of accidental pollution. Data from chemical analysis of surface waters conducted in EU countries show: AS PPP is often found in surface waters, threatening aquatic fauna [50-52].

Let us turn to the report of the European Environment Agency (EEA) [53]. It is compiled using data obtained from EU Member States after monitoring surface and groundwater. It has been conducted over the last six years in accordance with the River Basin Management Plans (RBMPs) of the EU Water Framework Directive [2]. It contains data on more than 130,000 water bodies across Europe. This is a serious well-founded document. Thus, this report states that less than half of European rivers, lakes and estuaries have achieved good ecological status. Only $40 \%$ of surface water bodies are in good ecological condition, despite significant political and management initiatives in recent decades to preserve and restore them, with lakes and coastal waters in better ecological condition than rivers and transitional waters. Approximately the same percentage $(38 \%)$ of surface water bodies is in good chemical condition, $46 \%$ have not reached this characteristic and for $16 \%$ this condition is unknown. These statistics are quite convincing. In most EU Member States, the poor chemical status of surface waters is due to the presence of several priority substances, the most common of which are mercury and brominated biphenyl ethers. Non-diffusion sources of agricultural origin account for $38 \%$ of the chemical load on surface waters. Isoproturon and hexachlorocyclohexane were among the priority substances belonging to the AS of the PPP, which cause pollution of more than 100 water bodies of surface waters out of the total number of 111062. Priority PPPs active substances such as trifluralin, chlorfenvinphos, atrazine, simazine, alachlor and pentachlorophenol have led to the non-recognition of about 15 surface water bodies in the EU in terms of good chemical status.

Monitoring of residual amounts of 49 AS PPPs in more than 2000 samples of surface and groundwater, conducted in Hungary in 1990-2015 showed that the main water pollutants were the active substances of herbicides used in the cultivation of corn - atrazine, acetochlor and iso-proturon, concentration in some cases it was $100000 \mathrm{ng} / \mathrm{l}$ [54].
Among the various water bodies under the EU Water Framework Directive [2], groundwater is generally in the best condition throughout Europe. Currently, 74\% of groundwater is in good chemical status, $25 \%$ has poor chemical status and $1 \%$ has unknown chemical status. In the EU, agriculture is the main polluter of groundwater through the use of fertilizers and PPP, which lead to diffuse pollution of groundwater with nitrates and others. Groundwater with the lowest chemical status is concentrated in areas with intensive agricultural production, and in some cases where there is or was heavy industry. A total of 160 chemicals are the cause of the poor chemical status of groundwater. Nitrates are the dominant groundwater pollutant in the EU. According to $24 \mathrm{EU}$ member states, this is the reason for the poor chemical status of $18 \%$ of groundwater. In addition to PPP, there are other important causes of poor chemical status, so $6,5 \%$ of groundwater fall into this category.

\section{Legislation of Ukraine in the field of water policy on the use of PPP in agricultural practice}

The presence of AS PPP in water in Ukraine is regulated by various legislative acts, including the Law on Drinking Water and Drinking Water Supply [55], the Order of the Ministry of Health of Ukraine On Approval of State Sanitary Norms and Rules "Hygienic Requirements for Drinking Water for Human Consumption" [56], Water Code of Ukraine [57], Resolution of the Cabinet of Ministers of Ukraine "Procedure for state monitoring of water" [58], the Law of Ukraine "On ensuring the sanitary and epidemiological well-being of the population" [59] and others. Most of these documents take into account the safety criteria and quality indicators of drinking, surface and groundwater established in the EU. Thus, in accordance with the State Sanitary Norms and Rules [56], the concentration of any individual AS PPP in drinking water should not exceed $0,1 \mu \mathrm{g} / 1$, and the total concentration, i.e. the sum of all individual detected AS PPP should not exceed $0,5 \mu \mathrm{g} / \mathrm{l}$. But unlike the EU Drinking Water Directive [4], the Ukrainian norm does not take into account the content in drinking water of significant metabolites of AS PPP, their reaction products and decomposition, which, of course, negatively affects the quality of drinking water. 
The Water Code of Ukraine and the Procedure for State Water Monitoring also take into account the main provisions of the EU Water Framework Directive [2] in the field of protection of surface and groundwater from pollution by hazardous substances, including PPP. However, it should be noted that these documents use terms that are not in the EU documents and which misinterpret the terms and concepts that have become entrenched in world environmental science, in particular in the field of protection of surface and groundwater from contamination by hazardous chemicals. The use of such terms undoubtedly complicates the intended use of Ukrainian documents. First of all, this applies to the following terms: "State social and hygienic monitoring", "Sanitary and hygienic safety" and "Hygienic requirements for drinking water intended for human consumption", the wording of which is based on the use of such a general term as hygiene. According to modern European and international legislation, it is impossible to carry out "social and hygienic monitoring" of water, but only environmental and chemical [2]. There can be no "sanitary and hygienic safety of water", but there can be only good ecological and chemical condition of surface waters and good chemical condition of groundwater [2]. There can be no "hygienic requirements for drinking water intended for human consumption", but there can only be standards for the chemical safety of drinking water, i.e. water intended for human consumption.

Undoubtedly, it is necessary to stop the arbitrary treatment of concepts and corresponding terms in domestic research and in the further drafting of regulations in the field of protection of man and the environment from chemical pressure. We are obliged to do this not only by integration with the laws of the EU, but also by the Order of the Cabinet of Ministers of Ukraine of 20.01.2016 № 94-r "On Recognition of repealed and not applicable in Ukraine, acts of sanitary legislation" [60], according to which in Ukraine the sanitary norms, rules and DSTU of the former USSR and the USSR have lost force. This Order, among others, specifies "sanitary and hygienic, sanitary and hygienic rules and regulations and sanitary regulations".

In connection with the problem covered, it is impossible not to pay attention to the issue of misuse in Ukraine (in scientific publications and in everyday life) of such terms as ecology and environment and derivatives of these terms ecological and environmental and in cases where the term ecology is replaced by the term pollution. Ecology is a branch of the science of biology that studies the interactions between living organisms and the environment (Cambridge English Dictionary). The environment is the air, water and land where people, animals and plants live (Cambridge English Dictionary). In this regard, the term environmental is a concept that refers to the environment, and the term ecological is a purely scientific concept that refers to the science of ecology. Therefore, the use of the terms ecology and ecological in solving the problem of minimizing pollution of surface and groundwater by the residues of AS PPP does not allow to clearly formulate and solve problems to be solved by specialists working in the field of water protection. Nevertheless, we have a successful "Institute of Hygiene and Ecology", "environmentally friendly production" and "environmentally friendly products". The substitution of the scientific interpretation of the term ecology has led to the fact that environmental problems in Ukraine are often tried to solve by specialists who are far from real ecological knowledge.

Since 2019, Ukraine has introduced European approaches to the implementation of the water monitoring system [58, 61] in accordance with the EU Water Framework Directive [2]. The new system provides for a six-year cycle of monitoring and classification of waters using 5 classes of ecological status (excellent, good, satisfactory, bad and very bad) and 2 classes of chemical status (good, failure to achieve good).

Determination of the chemical status of surface water mass should be carried out using environmental quality standards (EQS) (in Ukrainian regulations, these are "environmental" quality standards) in accordance with the EU Water Framework Directive 2000/60 using two levels of concentration of priority pollutants - maximum permissible concentration and average annual concentration.

The problem of ecological status of water bodies is relevant for all water basins of Ukraine. In most water bodies, this condition is classified as "bad" and "very bad". The most acute situation is observed in the basins of the Dnieper, the Seversky Donets, the rivers of the 
Azov Sea, some tributaries of the Dniester and the Western Bug, where water quality is defined as "very dirty" [62].

Order of the Ministry of Ecology and Natural Resources of Ukraine №45 of 06.02.2017 approved a list of pollutants to determine the chemical status of surface water, which includes 85 chemicals, 28 of which are active substances PPPs, the content of which should be monitored during surface water monitoring [63].

State registration of PPPs in the EU is a responsible and well-thought-out document, which is the main element of the barrier to the use of substandard PPPs. It allows the sale and use of only approved pesticide formulations based on the results of toxicological studies and evaluation of the behavior of their active substances in the environment in accordance with the physicochemical properties. Most developing countries have limited capacity to conduct their own PPPs tests, and they generally adopt the regulatory criteria of developed countries. It should be noted that in order to use the normative safety criteria for PPPs of developed countries for humans and the environment, as well as agricultural practice, it is necessary to adhere to the principles of Good Agricultural Practice (GAP), Good Plant Protection Practice (GPPP) and Good Laboratory Practice (GLP). Due to the fact that in Ukraine, as a rule, foreign-made PPPs is subject to state registration, which have passed the necessary tests in the EU or OECD countries and according to the results of these tests are registered for use in agricultural practice of these countries. experiments to develop parameters that characterize the behavior of AS PPPs in water, which are used to calculate PECsw as these parameters cannot differ from the parameters obtained in the EU. Despite the fact that the practice of using PPPs in agriculture in Ukraine differs from the European one not for the better, the use of PEC AS PPPs of European countries, which is registered in Ukraine, still allows to estimate the risk to humans and the environment associated with the use of registered PPPs. In this regard, the values of the PEC of the AS PPPs in soil, surface and groundwater and air, which characterize the risk to humans and non-target organisms, must be given in the dossier submitted by the applicant for registration of PPPs in Ukraine.
The main tool for assessing the chemical status of surface and groundwater in Ukraine, their safety for humans and the environment and the real burden on humans and the environment in connection with the use of PPPs in agricultural practice can only be monitoring the concentration of PPPs in water bodies. It was noted above that since 2019, Ukraine has introduced European approaches to water monitoring in accordance with the requirements of the EU Water Framework Directive 2000/60 and approved the Procedure and Program of state water monitoring [58, 61]. In 2021, Ukraine plans to create 4 modern laboratories for monitoring the chemical status of water bodies [63]. Even with the projected expansion of the capacity of these laboratories in 2022, it will be possible to monitor only about $7 \%$ of surface water bodies in Ukraine. For comparison, in France, $50 \%$ of surface waters are monitored.

In this context, it should be noted that the laboratory service of the Ministry of Health of the former USSR had sufficient experience in determining pesticide residues in food and the environment, which led to its participation in the All-Union monitoring of pesticide residues in agricultural products. nutrition, drinking water and ambient air, conducted by 15 union republics and 2000 SES of various levels in 1984-1991, the results of which were processed and evaluated on the basis of ECOGINTOX (now LI Medved's Reseach Centre of Preventive Toxicology, Food and Chemical Safety Ministry of Health Ukraine (State Enterprise), (Kyiv, Ukraine) for a number of years, the content of pesticides in the groundwater of the Crimean region has been monitored [64]. In our opinion, in order to draw up realistic river basin management plans for Ukraine in terms of achieving good surface water status associated with the use of PPPs in agricultural practice, especially with the need for experimental monitoring and rapid response in case of emergency pollution related to PPPs, it would be expedient to involve the LI Medved's Reseach Centre of Preventive Toxicology, Food and Chemical Safety Ministry of Health Ukraine (State Enterprise), (Kyiv, Ukraine) to this activity. Qualified staff and the necessary tools for this are available. 


\section{REFERENCES}

1. Ongley ED. Control of Water Pollution from Agriculture. FAO Irrigation and Drainage Papers. 1996; 101.

2. Directive 2000/60/EC of the European Parliament and of the Council of 23 October 2000 establishing a framework for Community action in the field of water policy. Official Journal of the European Communities. 2000;327:1-72.

3. Blessing A. Pesticides and Water Quality: Principles, Policies, and Programs. Dow Elsanko, United States, Environmental Protection Agency, Purdue University; 1995. 57.

4. Council Directive 98/83 EC of 3 November 1998 on the quality water intended for human consumption. Official Journal of the European Union. 1998;330:32-54.

5. Holvoet K, Seuntjens P, Vanrolleghem PA. Monitoring and modeling pesticide fate in surface waters at the catchment scale. Ecological modeling. 2007;209:53-64.

6. Leu C, Singer H, Stamm C, Muller SR, Swarzenbach RP. Variability of herbicide losses from 13 fields to surface water within a small catchment after a controlled herbicide application. Environ. Sci. Technol. 2004;38:3835-41.

7. Hankinson G, Welland G. The effectiveness of a stewardship campaign in Seven Trent Water. In: Proceedings of the BCPC Symposium №78: Pesticide Behavior in Soils and Water. 2001;325-33.

8. Mason P. Point source contamination of surface water by pesticides. Ph.D. Dissertation. Coventry University in Collaboration with ADAS and Horticulture Research International, UK; 2003. 365 p.

9. Holvoet K, Van Griensven A, Seuntjens P, Vanrolleghem PA. Sensitivity analysis for hydrology and pesticide supply towards the river in SWAT. Phys. Chem. Earth. 2005;30:518-26.

10. Knauer K. Pesticide in surface waters: a comparison with regulatory acceptable concentrations (RACs) determined in the authorization process and consideration for regulation. Environ Sci Eur. 2016;28(1):13.

11. Bach M, Huber A, Frede H. Input pathways and river load of pesticides in Germany - a national scale modeling assessment. Water Sci. Technol. 2001;43(5):261-8.

12. Wolfe ML. Hydrology. In: Ritter F, Shirmohammadi A, editors. Agricultural Nonpoint Source Pollution: Watershed Management and Hydrology. CRC Press LLC, Florida; 2001. 1-27.

13. Leonard RA. Movement of pesticides into surface waters. In: Cheng HH, editor. Pesticides in the Soil Environment: Process, Impacts, and Modeling; SSSA Book Series №2. Soil Science Society of America, Madison, WI, USA; 1990. 303-49.

14.Wu Q, Riise G, Lundekvam H, Mulder J, Haugen LE. Influence of suspended particles on the run-off of pesticides from an agricultural field at Askim, SE-Norway. Environ. Geochem. Health. 2004;26:295-302.

15. Muller K, Deurer M, Hartmann H, Bach M, Spiteller M, Frede HG. Hydrological characterization of pesticide loads using hydrograph separation at different scales in a German catchment. J. Hydrol. 2003;273:1-17.
16. Kerle EA, Jenkins JJ, Vogue PA. Understanding pesticide persistence and mobility for groundwater and surface water protection. Oregon State University EM 8561-E. Reprinted: April, 2007. 8 p.

17. Gil Y, Sinfort C. Emission of pesticides to the air during sprayer application: a bibliographic review. Atmos. Environ. 2005;39:5183-93.

18. Neuman M, Schulz R, Shafer K, Muller W, Mannheller W, Liess $M$. The significance of entry routes as point and nonpoint sources of pesticides in small streams. Water. Res. 2002;36:835-42.

19. Ropke B, Bach M, Frede HG. DRIPS - a DSS for estimating the input quantity of pesticides for German river basins. Environ. Model. Softw. 2004;19:1021-8.

20. Capel PD, Larson SJ, Winterstein TA. The behavior of thirty-nine pesticides in surface waters as a function of scale. Hydrol. Process. 2001;15:1251-69.

21. McBride DK. Managing pesticides to prevent groundwater contamination. North Dakota State University, Extention Service, Publication E-979; 1989.

22. Kreuger J. Pesticides in stream water within an agricultural catchment in southern Sweden, 1990-1996. Sci. Total Environ. 1998;216:227-51.

23. Vassiliou G. Factors affecting risk assessment of pesticides in water bodies: a review. MOJ Toxicol. 2016;2(1):26-32.

24. Toshiyuki Katagi. Direct photolysis mechanism of pesticides in water. J. Pestic. Sci. 2018;43(2):57-72.

25. Kegley SE, Hill BR, Orme S, et.al. PAN Pesticide Database, Pesticide Action Network. North America; 2014.

26. Warren N, Allan IJ, Carter JE, House WA, Parker A. Pesticides and other micro-organic contaminants in freshwater sedimentary environments - a review. Appl. Geochem. 2003;18;159-94.

27. Karickhoff SW, Brown DS, Scott TA. Sorption of hydrophobic pollutants on natural sediments. Water Res. 1979;13:421-8.

28.Ying GG, Williams B. Laboratory study on the interaction between herbicides and sediments in water systems. Environ. Pollut. 2000;107:399-405.

29. Smalling KL, Aelion CM. Distribution of atrazine into three chemical fractions: impact of sediment depth and organic carbon content. Environ. Toxicol. Chem. 2004;23:1164-71.

30. Council Directive 98/83 EC of November 1998 on the quality of water intended for human consumption. Official Journal of the European Union. 1998;330:32-54.

31. European Union Directive 2008/105/EC of the European Parliament and of the Council of the 16 December 2008 on environmental quality standards in the field of water policy. Official Journal of the European Union. 2008;348:84-97.

32. Directive 2013/39/EU of 12 August 2013 amending Directives 2006/60/EC and 2008/105/EC as regards priority substances in the field of water policy. Official Journal of the European Union. 2013;226.

33. Directive 2006/118/EC of 12 December 2006 on the protection of ground water against pollution and deteriora- 
tion// Official Journal of the European Union. 2006;372:19-31.

34.Regulation (EC) No 1107/2009 of the European Parliament and of the Council of 21 October 2009 concerning the placing of plant protection products on the market and repealing Council Directives 79/117/EEC and 91/414/EEC. Official Journal of the European Union. - 2009;309:1-50.

35. Commission Implementing Regulation (EU) No 540/2011 of 25 May 2011 implementing Regulation (EC) No $1107 / 2009$ of the European Parliament and of the Council as regards the list of approved active substances. Official Journal of the European Union. 2011;153:1

36. Commission Regulation (EU) No 283/2013 of 1 March 2013 setting out the data requirements for active substances, in accordance with Regulation (EC) No 1107/2009 of the European Parliament and of the Council concerning the placing of plant protection products on the market. Official Journal of the European Union. 2013;93:1-84.

37. Commission Regulation (EU) No 284/2013 of 1 March 2013 setting out the data requirements for plant protection products, in accordance with Regulation (EC) No 1107/2009 of the European Parliament and of the Council concerning the placing of plant protection products on the market. Official Journal of the European Union. 2013;93:85-152.

38. Gustafson DI. Groundwater ubiquity score: a simple method for assent pesticide leachability. Environmental Toxicology and Chemistry. 1989;8(4):339-57.

39. Chmil VD. K probleme izucheniya sudby deystvuyushchikh veshchestv sredstv zashchity rasteniy v pochve. Suchasni problemi toksikologiï. kharchovoï ta khimichnoï bezpeki. 2016;2(74):32-44.

40. Predicted environmental concentration www.eea.eu>glossary

41. Vassiliou G. Factors affecting risk assessment of pesticides in water bodies: a review. MOJ Toxicol. 2016;2(1):26-32.

42. Pellizzato F. Environmental Risk Assessment, Pesticide and Biocide. Encyclopedia of Toxicology, Third Edition; 2014.

43. Nikinmaa M. Modeling Toxicity An Introduction to Aquatic Toxicology. 2014.

44. Generic guidance for FOCUS surface water Scenarios. Version:1.4, May, 2015; 367.

45. Evaluation Manual for the Authorisation of plant protection products according to Regulation (EC) No 1107/2009 EU part Plant protection products Chapter 6 Fate and behavior in the environment; behavior in surface water, sediment and sewage treatment plants (STP) version 2.4; January 2020 Board for the Authorization of plant protection products and biocides, $18 \mathrm{p}$.

46. Jarvis NE. The MACRO model (version 5.0). Technical Description. 2003. http://bgf.mv.slu.se/ShowPage.cfm? OrgenhetSida.ID=5658(16/1/2007).

47.Carsel RF, Imhoff JC, Hummel PR, Cheplick JM, Donigian Jr, A.S.-2003. PRZM-3, A Model for Predicting Pesticide and Nitrogen Fate in the Crop Root and Unsaturated Soil Zones: Users Manual for Release 3.12.Center for Exposure Assessment Modeling (CEAM), U.S. Environmental Protection Agency (USEPA), Athens, GA, USA.
48. Horst MMS, Adriaanse PI, Beltman WHJ, Van den Berg F. Manual of FOCUS TOXSWA version 1.1.1 Draft 27.Alterra, Wageningen, the Netherlands. -2002. 62 p.

49. Generic Guidance for Tier 1 FOCUS Ground Water Assessment. Version: 2.2. 2014.

50. Bundschuh M, Goedkoop W, Kreuger J. Evaluation of pesticide monitoring strategies in agricultural streams based on the toxic-unit cocept-experiences from long-term measurements. Sci. Tot. Environ. 2014;484:84-91.

51. Muller K, Bach M, Hartmann H, Spiteller M, Frede H. Point ad nonpoint-source pesticide contamination in the Zwester Ohm catchment, Germany. J. Environ. Qual. 2002;31:309-18.

52.Chevre N, Loepfe C, Singer H, Stamm C, Fenner K, Esher $\mathrm{B}$. Including mixtures in the determination of water quality criteria for herbicides in surface water. Environ. Sci. Technol. 2006;40:426-35.

53. EEA Report. European waters Assessment of status and pressures 2018. 2018;7:85 p.

54. Szekacs A, Mortl M, Darvas B. Monitoring Pesticide Residues in Surface and Ground Water in Hungary:Surveys in 1990-2015. Water: Analysis, Treatment, and Reuse. 2015;2015:16 p.

55. Zakon o pityevoy vode i pityevom vodosnabzhenii (s izmeneniyami ot 6.10.2012 №5459-VI).

56. Nakaz MOZ Ukrainy vid 12.05.2010 №400 Pro zatverdzhennia Derzhavnykh sanitarnykh norm ta pravyl «Hihiienichni vymohy do vody pytnoi, pryznachenoi dlia spozhyvannia liudynoiu» (iz zminamy, vnesenymy zghidno z Nakazom MOZ №505(1043-11) vid 15.08.2011).

57. Vodnyi kodeks Ukrainy. Postanova Verkhovnoi Rady Ukrainy vid 06.06.1995 №214/95-VR (Vidomosti Verkhovnoi Rady Ukrainy (VVR), 1995, №24, st.189).

58. Postanova Kabinetu Ministriv Ukrainy «Poriadok zdiisnennia derzhavnoho monitorynhu vod» vid 19.09 .2018 r. za №758.

59. Zakon Ukrainy «Pro zabezpechennia sanitarnoho ta epidemichnoho blahopoluchchia naselennia» vid 24.02.1994 №4004-XII.

60. Rozporiadzhennia Kabinetu Ministriv Ukrainy vid 20.01.2016 r. №94-r «Pro vyznannia takymy, shcho vtratyly chynnist, ta takymy, shcho ne zastosovuiutsia na terytorii Ukrainy, aktiv sanitarnoho zakonodavstva»

61. Nakaz Derzhavnoho ahentstva vodnykh resursiv Ukrainy vid 11.06.2019 r. № 336 «Pro zatverdzhennia prohram monitorynhu vod».

62. Ekolohichna sytuatsiia ta stan pytnykh vod Ukrainy www.ecollague.net>diialnist.

63. Nakaz Ministerstva ekolohii ta pryrodnykh resursiv Ukrainy vid 06.02.2017 r. №45 Pro zatverdzhennia Pereliku zabrudniuiuchykh rechovyn dlia vyznachennia khimichnoho stanu masyviv poverkhnevykh i pidzemnykh vod ta ekolohichnoho potentsialu shtuchnoho abo istotno zminenoho masyvu poverkhnevykh vod.

64. Chmil VD. Rakitskiy VN. Bondarenko VP. Gigiyenicheskaya otsenka podzemnykh vod Kryma V usloviyakh khimizatsii selskogo khozyaystva. Gigiyena primeneniya. toksikologiya pestitsidov i polimernykh materialov. 1983;13:93-4. 


\title{
ДО ПРОБЛЕМИ ВИВЧЕННЯ ПОВЕДІНКИ ДІЮЧИХ РЕЧОВИН ЗАСОБІВ ЗАХИСТУ РОСЛИН У ПОВЕРХНЕВИХ I ПІДЗЕМНИХ ВОДАХ В УКРАЇНІ ВІДПОВІДНО ДО НОРМАТИВІВ ЕВРОПЕЙСЬКОГО СОЮЗУ (ЕС)
}

\author{
В.Д. Чміль, Г.І. Петрашенко
}

Державне підприємство «Науковий центр превентивної токсикології, харчової та хімічної безпеки імені академіка Л.І. Медведя Міністерства охорони здоров’я України», м. Київ, Україна

PЕЗЮМЕ. Мета - розгляд вивчення долі і поведінки діючих речовин засобів захисту рослин (ДР ЗЗР) у поверхневих і підземних водах у країнах $E C$, якості поверхневих і підземних вод, що пов'язане з використанням ЗзР в Україні та надання пропозицій щодо вдосконалення вітчизняного моніторингу екологічного та хімічного стану поверхневих $і$ підземних вод України відповідно до нормативів $E C$.

Матеріали та методи. Наявність ДВ ЗЗР у воді в Україні регламентується різними законодавчими актами, включаючи Закон про питну воду та питне водопостачання, Наказ МОЗ України Про затвердження Державних санітарних норм та правил «Гігієнічні вимоги до води питної, призначеної для споживання людини», Водний кодекс України, Постанову Кабінету Міністрів України «Порядок здійснення державного моніторингу вод», Закон України «Про забезпечення санітарного та епідемічного благополуччя населення» та ін. У більшості иих документів враховуються критерії безпеки та показники якості питних, поверхневих і підземних вод встановлені в ЄС. У Водному кодексі України та Порядку здійснення державного моніторингу вод також враховані основні положення рамкової водної директиви СС у галузі захисту поверхневих і підземних вод від забруднення небезпечними речовинами, включаючи ЗЗР. Однак доводиться констатувати, що в иих документах використовуються терміни, які відсутні в документах $Е С$ і які помилково трактують терміни і поняття, які закріпилися у світовій науці щодо навколишнього середовища, зокрема в галузі охорони поверхневих і підземних вод від забруднення небезпечними хімічними речовинами. Використання таких термінів, безперечно, ускладнює використання українських документів за призначенням.

Висновки. Сформульовані пропозиції щодо недоречності використання в законодавчих актах України в галузі водної політики деяких понять і термінів, які не відповідають вимогам СС та втратили чинність і не застосовуються на території України згідно з Розпорядженням Кабінету Міністрів України №94-р від 20.01.2016р .

При державній реєстрації в Україні ЗЗР іноземного виробництва, які пройшли необхідні випробування у країнах ЄС, в досьє на формуляцію, яку реєструє і подає Заявник, обов'язково повинні бути наведені величини прогнозованих концентрацій ДР ЗЗР у грунті, поверхневих і підземних водах та повітрі, які характеризують ризик для людини і нецільових організмів.

Ключові слова: діючі речовини засобів захисту рослин, поверхневі води, підземні води, стандарти якості навколишнього середовища, прогнозовані екологічні концентрації діючих речовин засобів захисту рослин, моніторинг екологічного та хімічного стану поверхневих і підземних вод.

\section{К ПРОБЛЕМЕ ИЗУЧЕНИЯ ПОВЕДЕНИЯ ДЕЙСТВУЮЩИХ ВЕЩЕСТВ СРЕДСТВ ЗАЩИТЫ РАСТЕНИЙ В ПОВЕРХ- НОСТНЫХ И ПОДЗЕМНЫХ ВОДАХ В УКРАИНЕ В СООТВЕТСТВИИ С НОРМАТИВАМИ ЕВРОПЕЙСКОГО СОЮЗА (ЕС)}

\section{В.Д. Чмиль, А.И. Петрашенко}

Государственное предприятие «Научный центр превентивной токсикологии, пищевой и химической безопасности имени академика Л.И. Медведя Министерства здравоохранения Украины», г. Киев, Украина

РЕЗЮМЕ. Цель - рассмотрение изучения судьбы и поведения действующих веществ средств защиты растений (ДВ СЗР) в поверхностных и подземных водах в странах EC, качества поверхностных и подземных вод, что связано с использованием СЗР в Украине и предоставления предложений по совершенствованию отечественного мониторинга экологического и химического состояния поверхностных и подземных вод Украины в соответствии с нормативами ЕС.

Материалы и методы. Наличие ДВ СЗР в воде в Украине регламентируется различными законодательными актами, включая Закон о питьевой воде и питьевом водоснабжении Приказ МЗ Украины Об утверждении Государственных санитарных норм и правил «Гигиенические требования к воде питьевой, предназначенной для потребления человеком», Водный кодекс Украины, Постановление Кабинета Министров Украины «Порядок осуществления государственного мониторинга вод», Закон Украины «Об обеспечении санитарного и эпидемического благополучия населения» и др. В большинстве этих документов учитываются критерии безопасности и показатели качества питьевых, поверхностных и подземных вод, установленные в ЕС. В Водном кодексе Украины и Порядке осуществления государственного мониторинга вод также учтены основные положения рамочной водной директивы ЕС в области защиты поверхностных и подземных вод от загрязнения опасными веществами, включая СЗР. Однако приходится констатировать, что в этих документах используются термины, которые отсутствуют в документах ЕС и ошибочно трактуют термины и понятия, которые закрепились в мировой науке по окружающей среде, в частности в области охраны поверхностных и подземных вод от загрязнения опасными химическими веществами. Использование таких терминов, безусловно, затрудняет использование украинских документов по назначению.

Выводы. Сформулированы предложения о неуместности использования в законодательных актах Украины в области водной политики некоторых понятий и терминов, которые не соответствуют требованиям ЕС, потеряли силу и не применяются на территории Украины согласно Распоряжению Кабинета Министров Украины №94-р от 20.01.2016 г.

При государственной регистрации в Украине СЗР иностранного производства, которые прошли необходимые испытания в странах EC, в досье на формуляцию, которую регистрирует и подает Заявитель, обязательно должны быть приведены величины прогнозируемых концентраций ДР СЗР в почве, поверхностных и подземных водах и воздухе, характеризующих риск для человека и нецелевых организмов.

Ключевые слова: действующие вещества средств защиты растений, поверхностные воды, подземные воды, стандарты качества окружающей среды, прогнозируемые экологические концентрации действующих веществ средств защиты растений, мониторинг экологического и химического состояния поверхностных и подземных вод. 